\title{
1 Microfluidics-Enabled Digital Isothermal Cas13a Assay
}

2 Frank X. Liu ${ }^{1,}+$, Johnson Q. Cui ${ }^{1,}$, , Hojeong Park ${ }^{2,3,}$, Ka Wai Chan ${ }^{4}$, Tyler Leung ${ }^{4}$, Ben Zhong Tang ${ }^{2,3,5}$,

$3{ }^{*}$, Shuhuai $\mathrm{Yao}^{1,2, *}$

$4 \quad{ }^{1}$ Department of Mechanical and Aerospace Engineering, The Hong Kong University of Science and

5 Technology, Clear Water Bay, Kowloon, Hong Kong

$6 \quad{ }^{2}$ Department of Chemical and Biological Engineering, The Hong Kong University of Science and

7 Technology, Clear Water Bay, Kowloon, Hong Kong

$8 \quad{ }^{3}$ Department of Chemistry, Hong Kong Branch of Chinese National Engineering Research Center for

9 Tissue Restoration and Reconstruction, The Hong Kong University of Science and Technology, Clear

10 Water Bay, Kowloon, Hong Kong

$11{ }^{4}$ DiagCor Life Science Limited, Kowloon Bay, Kowloon, Hong Kong

$12 \quad{ }^{5}$ Shenzhen Institute of Molecular Aggregate Science and Engineering, School of Science and

13 Engineering, The Chinese University of Hong Kong, Shenzhen,2001 Longxiang Boulevard, Longgang

14 District, Shenzhen City, Guangdong 518172, China

$15 \dagger$ indicates these authors contributed equally.

16 * corrensponding emails. tangbenz@ust.hk, meshyao@ust.hk

17 
medRxiv preprint doi: https://doi.org/10.1101/2021.08.18.21262201; this version posted August 24, 2021. The copyright holder for this preprint (which was not certified by peer review) is the author/funder, who has granted medRxiv a license to display the preprint in perpetuity.

It is made available under a CC-BY-NC-ND 4.0 International license .

\section{Abstract}

22 The isothermal molecular diagnosis with CRISPR has attracted particular interest for the sensitive,

23 specific detection of nucleic acids. However, most of the assays with Cas enzymes were performed

24 in bulk assays using multistep approaches and hard to realize quantitative detection. Herein, we

25 report Microfluidics-Enabled Digital Isothermal Cas13a Assay (MEDICA), a digital format of

26 SHERLOCK with enhanced robustness and sensitivity. We first address the macromolecular

27 crowding problems when combining the recombinase polymerase amplification (RPA) and

28 Cas13a detection into a one-pot SHERLOCK assay. After the assay optimization, the enhanced

one-pot SHERLOCK (E-SHERLOCK) achieves high robustness and 200-fold increased sensitivity. Leveraging droplet microfluidics, we streamline the E-SHERLOCK to eliminate

undesired input targets caused by pre-amplification before partition, enabling background-free promising for the next generation of point-of-care diagnostics.

Rapid, robust, and inexpensive diagnostics are crucial in defense against the spread of viral

40 infections such as SARS-CoV, MERS-CoV, Ebola, Zika, avian, and swine influenza. The COVID

$41-19$ pandemic highlights the unprecedented demand for rapid and sensitive nucleic acid detection

42 assays, which play a pivotal role in routine diagnosis, mechanistic and transmission studies,

43 vaccine development, and therapeutics for COVID-19 ${ }^{1}$. Quantitative polymerase chain reaction 
medRxiv preprint doi: https://doi.org/10.1101/2021.08.18.21262201; this version posted August 24, 2021. The copyright holder for this preprint (which was not certified by peer review) is the author/funder, who has granted medRxiv a license to display the preprint in perpetuity.

It is made available under a CC-BY-NC-ND 4.0 International license .

44 (qPCR) has long been regarded as a gold standard for viral infection diagnosis ${ }^{2}$. However, as a 45 centralized laboratory-based testing paradigm for viral diagnostics, PCR assays depend on 46 specifically designed TaqMan probes as well as precise thermal cycling, limiting their

47 deployability for community tests.

Recently, clustered regularly interspaced short palindromic repeats (CRISPR) and CRISPRassociated (CRISPR-Cas) endonucleases are leveraged for nucleic acid detection through unique collateral trans-cleavage ${ }^{3-10}$. Programmable crRNA-guided CRISPR Cas12 and Cas13 can

51 specifically recognize the target sequence to promote trans cleavage of surrounded single-stranded 52 reporters ${ }^{11,12}$. Combined with a separate step of isothermal recombinase polymerase amplification

53 (RPA) preamplification, Cas13a based SHERLOCK (Specific High-sensitivity Enzymatic 54 Reporter unlocking) and Cas12a based DETECTR (DNA endonuclease-targeted CRISPR trans reporter) achieved attomolar sensitivity and single nucleotide polymorphism (SNP) identification 56 ability ${ }^{13,14}$. Due to the strong collateral activity Cas $13 \mathrm{a}^{8,15,16}$, the SHERLOCK assay demonstrated 57 single-molecule detection ability when performing using a multistep process. However, the 58 multistep schemes not only increase the risk of contamination and human errors but also impose 59 difficulties and sample loss for the quantification of the target molecules. Even though SHERLOCK can perform at a one-pot scheme, the macromolecular crowding agent issue and enzymatic incompatibility between RPA and CRISPR reactions result in less robust and sensitive results compared to two-step reactions ${ }^{17}$. In addition, the one-pot reaction relies on the use of

63 standard curves and endogenous controls to obtain relative quantification, which has been shown 64 to have significant variations ${ }^{18,19}$. In contrast to the standard curve calibration approach, absolute 65 quantification with improved precision and accuracy has been achieved by digital $\mathrm{PCR}^{20}$ and 
medRxiv preprint doi: https://doi.org/10.1101/2021.08.18.21262201; this version posted August 24, 2021. The copyright holder for this preprint (which was not certified by peer review) is the author/funder, who has granted medRxiv a license to display the preprint in perpetuity.

It is made available under a CC-BY-NC-ND 4.0 International license .

67 mixture is partitioned into a sufficient number of individual reactions so that either zero or one of

68

the target nucleic acid molecules is being amplified in each partition, and the assay result is evaluated based on a simple positive-negative counting of the individual partitions based on the end-point fluorescence measurement ${ }^{19}$. Yet, as far as we know, there is no digital SHERLOCK assay available.

Different from PCR or LAMP that needs to be triggered by elevating the temperature, the isothermal RPA and some of the CRISPR type V and VI endonucleases can react at room temperature $^{22-24}$ so that the reaction would start to amplify the targets before the sample partitioning into the nano-wells (e.g., QuantStudio 3D digital chips) or droplets using a simple flow-focusing system, which inevitably causes undesired overestimation due to pre-amplification 24-26. To minimize the premature target amplification, one remedy is to prepare the reaction mixture on ice and quickly load it for partition $^{27}$. Hence, unlike hot-start digital PCR and LAMP, the implementation of digital quantification of the near ambient temperature SHERLOCK needs a novel system for sample partitioning. Droplet microfluidics offers versatile yet controllable handling of samples and reagents in forming droplets, and thus can effectively avoid premature amplification before partitioning into droplets as well as facilitate combined amplification and trans-cleavage detection reactions in individual droplets.

In this work, we report Microfluidics-Enabled Digital Isothermal Cas13a Assay (MEDICA), the digital format of enhanced one-pot SHERLOCK (E-SHERLOCK). Digital quantification relies on a high signal-to-background ratio to convert the fluorescent signals of individual droplets to one or zero readouts, thus signal robustness and reproducibility are of great importance for digital quantification. However, when we conducted the one-pot SHERLOCK assay, the poor sensitivity and robustness of the reaction raised great concern. We identified the optimal reaction condition 
medRxiv preprint doi: https://doi.org/10.1101/2021.08.18.21262201; this version posted August 24, 2021. The copyright holder for this preprint (which was not certified by peer review) is the author/funder, who has granted medRxiv a license to display the preprint in perpetuity.

It is made available under a CC-BY-NC-ND 4.0 International license .

enzymatic incompatibility and addressed the macromolecular crowding agent issue of the all-inone SHERLOCK assay, allowing robust detection at a single copy per microliter. We further applied E-SHERLOCK assay into droplet microfluidics for digital quantification. Leveraging the microfluidic design, MEDICA uses droplet compartmentation technology that effectively prevents premixing by separation of the magnesium initiator from the target-included master mix, which allows MEDICA to eliminate undesired premature amplification. Moreover, MEDICA showed an excellent signal-to-background ratio upon coordination of the reporter concentration with the collateral reporting, enabling near background-free absolute quantification. Benefit from the concentrated reaction within a picolitre droplet and the enhanced molecule mobility, MEDICA achieved qualitative detection within $10 \mathrm{~min}$ and quantitative detection within 25 min. Lastly, we applied MEDICA to detect both HPV 16 and HPV 18 for clinical validation. MEDICA successfully identified and quantified all viral HPV 16 and HPV 18 in clinical specimens, demonstrating excellent performance in line with qPCR results.

\section{Results}

\section{Overview of MEDICA for viral HPV Detection.}

We established the workflow of MEDICA and demonstrated its application for the detection of viral Human Papillomavirus (HPV) 16 and 18. HPV is critical for identifying the risk of HPVrelated cancers such as cervical cancer. Among all HPV types, HPV 16 and HPV 18 are accounted for the most precancerous lesions ${ }^{28}$. We designed two MEDICA sequences that include two sets of forward primers with overhanging T7 promoter, Cas13a crRNAs to recognize both HPV 16 and HPV 18 for specific and sensitive tests (Figure 1a). RPA is a magnesium acetate (MgOAc) initiation nucleic acid amplification near ambient temperature compared to hot start LAMP and 
medRxiv preprint doi: https://doi.org/10.1101/2021.08.18.21262201; this version posted August 24, 2021. The copyright holder for this preprint (which was not certified by peer review) is the author/funder, who has granted medRxiv a license to display the preprint in perpetuity.

It is made available under a CC-BY-NC-ND 4.0 International license .

$113 \mathrm{PCR}^{29,30}$. Since RPA starts as soon as MgOAc is added even at room temperature ${ }^{31,32}$, the

114 premature RPA amplification caused by directly mixing MgOAc with the master mix before

115 sample loading or partitioning would result in overestimated target input. To tackle this issue, we

116 separate $\mathrm{MgOAc}$ and the target-included master mix before loading them into the droplet generator.

117 Adopting a flow-flowing configuration with two sample inlets (Figure 1b), MgOAc and the target-

118 included master mix are loaded separately into the device and co-encapsulated into microdroplets

119 in fluorinated oil 7500 with 2.5\% EA surfactant. Thus, RPA is only triggered by MgOAc after

120 droplet formation. The droplet generator enables high throughput generation of monodisperse

121 droplets of $\sim 30 \mu \mathrm{m}$ in diameter at one $\mathrm{kHz}$, which is more rapid and efficient than nano-well-based

122 digital loading ${ }^{33,34}$. By droplet partitioning, a single target DNA is confined in a small volume in 123 which the signal can be amplified and concentrated for detection. The generated emulsions are

124 then incubated at $37{ }^{\circ} \mathrm{C}$ before fluorescence imaging. This one-pot reaction contains extensible

125 RPA amplification with T7 overhangs, RNA activator transcription by T7 RNA polymerase, and

126 CRISPR Cas13a ternary collateral detection (Figure 1c). During the one-pot enzymatic activity,

127 the unique adaptable reporting feature of Cas13a nuclease barely digests DNAs, leading to 128 extremely high sensitivity. Our droplet-based MEDICA allows absolute counting of the target

129 DNA molecules to achieve unprecedented accuracy. 
medRxiv preprint doi: https://doi.org/10.1101/2021.08.18.21262201; this version posted August 24, 2021. The copyright holder for this preprint (which was not certified by peer review) is the author/funder, who has granted medRxiv a license to display the preprint in perpetuity.

It is made available under a CC-BY-NC-ND 4.0 International license .

a

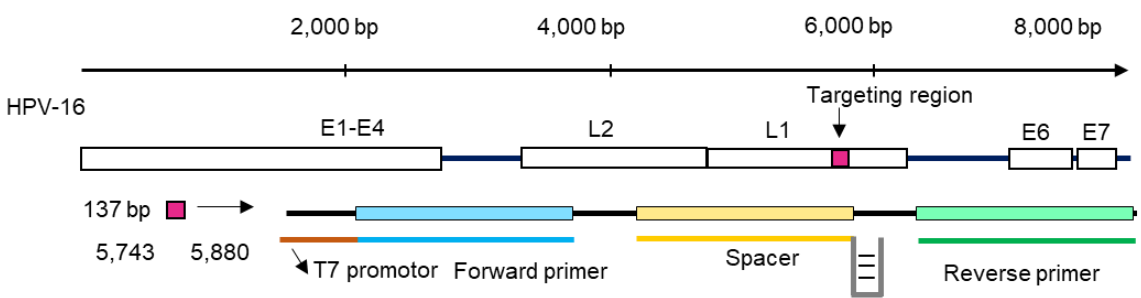

HPV-18

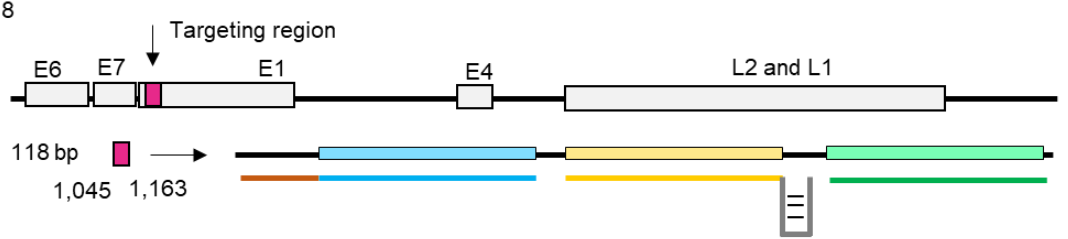

b Mastermix separation

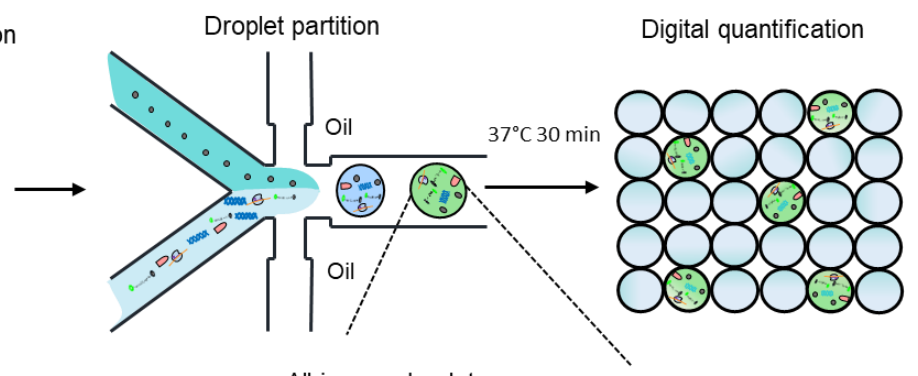

Target-included master mix

All-in-one droplet

C

Forward primer with

T7 sequence overhang

$\overrightarrow{\overrightarrow{111111111111}}$

Reverse Primer ................

RPA amplification
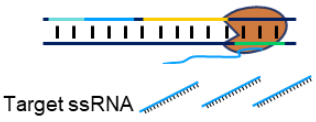

T7 RNA transcription

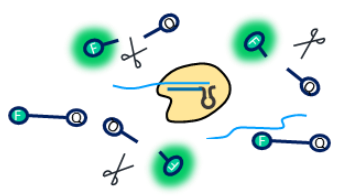

Cas13a readout

\begin{tabular}{|c|c|c|c|c|c|}
\hline$\longrightarrow$ & $\longleftarrow$ & $\beta$ & & 3 & 0 \\
\hline $\begin{array}{l}\text { Forward primer with } \\
\text { T7 sequence overhang }\end{array}$ & Reverse Primer & T7 RNA polymerase & Target ssRNA & Cas13a and crRNA & PolyU RNA reporter \\
\hline
\end{tabular}

131 Figure 1. Overview of targeting sequences and MEDICA process. a, The genome map of both

132 HPV 16 and HPV 18. The selected CRISPR detection regions of HPV 16 L1 and HPV 18 E1 are annotated with red lines in the genome, which covers the forward RPA primer with extended T7 
medRxiv preprint doi: https://doi.org/10.1101/2021.08.18.21262201; this version posted August 24, 2021. The copyright holder for this preprint (which was not certified by peer review) is the author/funder, who has granted medRxiv a license to display the preprint in perpetuity.

It is made available under a CC-BY-NC-ND 4.0 International license .

as soon as droplets are formed. After incubation at $37^{\circ} \mathrm{C}$ for $30 \mathrm{~min}$ RPA and Cas 13a reactions, the droplets are imaged by fluorescence microscopy and counted for quantification of the target molecule concentration. c, The all-in-one molecular reaction inside a droplet. With the initiation of MgOAc, RPA enzymes amplify the target sequence to generate numerous amplicons with a sequence extension of the $\mathrm{T} 7$ promoter region. Then T7 RNA polymerase transcripts target protospacer into RNAs to activate Cas13a for trans-cleavage reporting.

\section{Optimization of the one-pot SHERLOCK assay}

Combining RPA with Cas13a in a one-pot reaction with high sensitivity and reproducibility is critical to ensure the accuracy and robustness of the quantification results. Therefore, we started with assay development which is a prerequisite to digital quantification. However, when we conducted the one-pot assay directly combining the reagents used in the two-step SHERLOCK ${ }^{35}$, we found the results had dramatical fluctuation and thus compromised sensitivity compared to the two-step approaches (Figure 1a, supplementary S2). The digital quantification relies on the statistical calculation of the positive droplets that contain fluorescence signal higher than the threshold ${ }^{19}$. The irreproducibility of the reactions in droplets would result in massive rain droplets whose signals are between the positive and negative controls, leading to a high error to absolute quantification $^{36}$. Therefore, in circumventing these challenges, a compatible and robust one-pot SHERLOCK assay needs to be established in order to minimize the uncertainty in counting the positive droplets. These signal fluctuations and uncertainty are likely caused by the reaction component incompatibility and viscous condition ${ }^{17,37}$.

Subsequently, we performed multiple rounds of assay optimization to identify the key factors of this reaction. First, we investigated the components of the reaction buffer including pHs, salts, and 
medRxiv preprint doi: https://doi.org/10.1101/2021.08.18.21262201; this version posted August 24, 2021. The copyright holder for this preprint (which was not certified by peer review) is the author/funder, who has granted medRxiv a license to display the preprint in perpetuity.

It is made available under a CC-BY-NC-ND 4.0 International license.

162

163

164

165

166

167

168

169

170

171

172

173

174

175

176

177

178

179

180

181

182

183

184

other additives. We found the $60 \mathrm{mM} \mathrm{pH} \mathrm{7.5} \mathrm{Tris-} \mathrm{HCl}$ buffer with $80 \mathrm{mM} \mathrm{KCl}$ yielded the highest signal, much better than the HEPES buffer used for SHERLOCK detection (Figure $2 b$ and supplementary S3a). The commonly used RPA mixture is highly viscous due to the presence of a high molecular crowding agent to enhance the catalytic activity and increase specificity as well as sensitivity ${ }^{29}$. Macromolecular crowding increases the binding of polymerase to DNA and reduces the thermodynamic activity, resulting in localized reagent depletion ${ }^{38}$. Thus, additional components in low concentration are difficult to be distributed homogeneously. We then explored the influence caused by PEG 8000. The reaction was activated with the presence of PEG 8000 (Figure 2c), however, as the concentration of PEG 8000 increased over $5 \%$, the fluorescence signal of the one-pot reaction fluctuated dramatically. This result indicated that the collateral activity was affected by the viscosity of the reagent as the biomolecules of the Cas 13a system are restricted in RNA activator transcription, Cas13a ternary trans reporting. Compared to the hot-start PCR assisted by PEG, the molecule diffusion is enhanced with the high temperature where the non-concentration components are distributed homogenously. Hence, we chose $2.5 \%$ PEG 8000 to minimize the signal fluctuation caused by nonhomogeneous molecule distribution while maintaining robust detection performance. Moreover, we added $0.05 \%$ tween 20 , a surfactant commonly used in droplet microfluidics ${ }^{39}$, to reduce the viscosity even further (Supplementary S3c). We compared the viscosity of the final enhanced reaction buffer (e-reaction) with other PEGbased reaction buffers (Figure 2d). The optimal one-pot reaction buffer is less viscous than most of other PEG-based reaction buffers. These improvements decrease the viscosity of the reaction buffer, in another word, the molecule diffusion ability was increased at a lower temperature. To further enhance the detection ability, we optimized the primer concentration for this one-pot reaction (Supplementary S4a). $120 \mathrm{nM}$ and $360 \mathrm{nM}$ primers resulted in a strong fluorescence signal 
medRxiv preprint doi: https://doi.org/10.1101/2021.08.18.21262201; this version posted August 24, 2021. The copyright holder for this preprint (which was not certified by peer review) is the author/funder, who has granted medRxiv a license to display the preprint in perpetuity.

It is made available under a CC-BY-NC-ND 4.0 International license .

and $360 \mathrm{nM}$ primer performed better at $10 \mathrm{cp} / \mu \mathrm{L}$ concentration (Supplementary S4b). Besides, we optimized all the other related components including crRNA to Cas13a ratio, T7 RNA (Supplementary S4c and d).

After these major optimizations, we compared our E-SHERLOCK with the standard two-step SHERLOCK to test the sensitivity and specificity. The optimized assay indicated consistent detection ability (Figure 2e). Then we conducted the specificity of this assay to detect the HPV16 L1 gene, HPV18 E1 gene. Four synthetic plasmids containing HPV 16 L1 gene, HPV 18 E1 gene, SAR-CoV-2 ORF gene, and SAR-CoV-2 N gene, were applied. We spiked the targeted HPV 16 into the unrelated samples to compare the performance inside the complicated matrix (Figure $2 \mathrm{f}$ ). E-SHERLOCK demonstrated high specificity with spiked samples. Lastly, we evaluated the sensitivity of the E-SHERLOCK. It achieved $1 \mathrm{cp} / \mu \mathrm{L}$ in a bulk solution (Figure $2 \mathrm{~g}$ and Supplementary S7). The theoretical limit of detection (LOD) is $0.06 \mathrm{cp} / \mathrm{uL}$ (Supplementary S6). Compared to the initial one-pot assay, the optimized assay has improved both robustness and sensitivity of the assay (Supplementary S5). The optimized one-pot SHERLOCK increased a maximum of 76-fold of stability, and 200 times of sensitivity (Supplementary S5 and S6). We sought to verify the clinical performance of our enhanced one-pot SHERLOCK by conducting a clinical validation to detect both HPV 16 and HPV 18 (Figure 2h). Among other sexually transmitted diseases (STD) including Neisseria gonorrhoeae (NG) and Chlamydia trachomatis (CT), the one-pot SHERLOCK identified all clinical samples within $30 \mathrm{~min}$, which is in 100\% agreement with qPCR results (Table 1). 

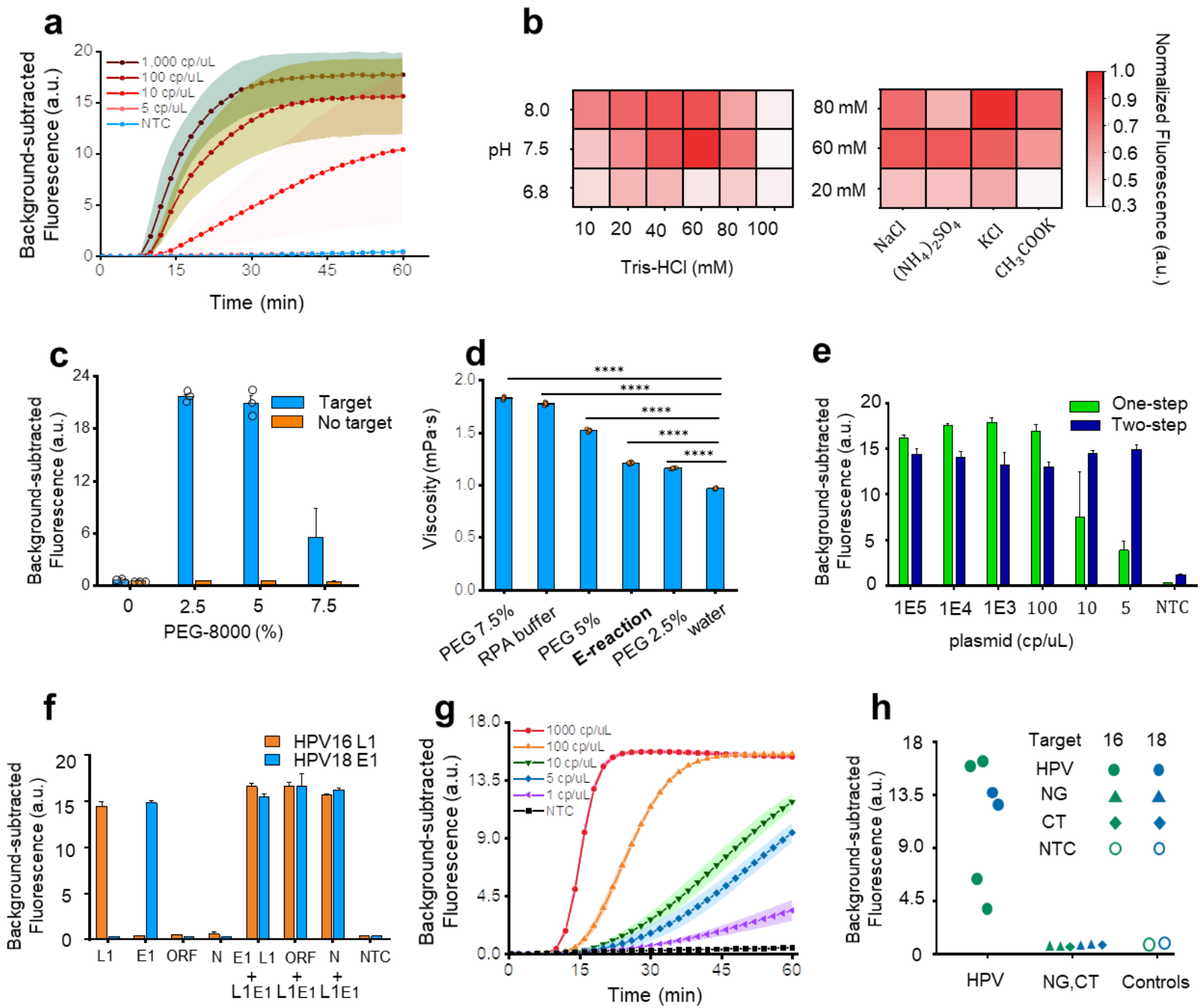

Figure 2. Construction of E-SHERLOCK. a, The fluorescence signals show a wide range of variations using the initial one-pot SHERLOCK in bulk for detection of synthetic HPV 16 plasmid from $1000 \mathrm{cp} / \mu \mathrm{L}$ to $5 \mathrm{cp} / \mu \mathrm{L}$. b, The $\mathrm{pH}$ and salt optimization for one-pot SHERLOCK. Tris-HCl of $\mathrm{pH} 6.8,7.5,8$, and different concentrations was compared. Sodium chloride $(\mathrm{NaCl})$, amino sulfate $\left(\left(\mathrm{NH}_{4}\right)_{2} \mathrm{SO}_{4}\right)$, potassium chloride $(\mathrm{KCl})$, and potassium acetate $\left(\mathrm{CH}_{3} \mathrm{COOK}\right)$ of different concentrations were compared. c, PEG 8000 of $0,2.5,5$, and $7.5 \%$ was compared. d, The viscosity comparison of different reaction conditions using different concentrations of PEG8000, the ereaction buffer represents the optimal reaction buffer. e, The comparison of two-step and the 
medRxiv preprint doi: https://doi.org/10.1101/2021.08.18.21262201; this version posted August 24, 2021. The copyright holder for this preprint (which was not certified by peer review) is the author/funder, who has granted medRxiv a license to display the preprint in perpetuity.

It is made available under a CC-BY-NC-ND 4.0 International license .

214

215

216

217

218

219

220

221

222

223

224

225

226

227

228

229

230

231

232

233

234

235

236

optimized one-pot SHERLOCK after $1 \mathrm{~h}$ using HVP 16 plasmid. f, The specificity of one-step SHERLOCK with or without spiked plasmid targets. ORF and N indicate the SARS-CoV-2 ORF gene and $\mathrm{N}$ gene, respectively. $\mathbf{g}$, The real-time fluorescence of the optimized one-pot assay for detection of a serial dilution of HPV 16 plasmid from $1000 \mathrm{cp} / \mu \mathrm{L}$ to $1 \mathrm{cp} / \mu \mathrm{L}$. $\mathbf{h}$, The clinical validation of E-SHERLOCK. HPV 16, HPV 18, NG, and CT samples were tested to verify the one-pot SHERLOCK performance. The green color group represents the HPV 16 detection while the blue group shows the HPV 18 diagnosis. For $\mathbf{a}$ and $\mathbf{g}$, the filled area represents the error bar (s.d.) of each group. For $\mathbf{c - f}$, the center is the mean of 3 technical replicates, while the error bar indicates the s.d. For $\mathbf{d}$, the two-tailed student's t-test; **** $\mathrm{P}<0.0001$. For $\mathbf{b}$ and $\mathbf{c}$, the concentration of plasmid HPV 16 is $10 \mathrm{cp} / \mathrm{uL}$. The NTC represents the non-template control.

\section{Real-time and end-point quantification with MEDICA}

The E-SHERLOCK achieved high sensitivity and robust detection ability. However, the reaction time (30-40 min) compared to the typical RPA reaction (20-30 min) is over-extended. Droplet digital methods can increase the localized reaction concentration thus shortening the reaction time. Additionally, the droplet digital technique offers more precise quantification results compared to real-time quantitative detection. Therefore, we applied droplet microfluidics to covert our optimal assay into digital format.

The droplet digital assay contains three steps, droplet partition, droplet incubation, and digital visualization. To realize the $\mathrm{MgOAc}$ and target-included master mix separation and mix, we separated the two phases and let them flow into a two-inlet droplet generator (Supplementary S8 a). Due to the different viscosity of the two phases, the pressures applied were adjusted to achieve an equal volume flow rate for mixing in droplets. The mixture of $\mathrm{MgOAc}$ and Target-included 
medRxiv preprint doi: https://doi.org/10.1101/2021.08.18.21262201; this version posted August 24, 2021. The copyright holder for this preprint (which was not certified by peer review) is the author/funder, who has granted medRxiv a license to display the preprint in perpetuity.

It is made available under a CC-BY-NC-ND 4.0 International license .

237

238

239

240

241

242

243

244

245

246

247

248

249

250

251

252

253

254

255

256

257

258

259 master mix was encapsulated into picoliter-sized water in oil droplets $(\sim 30 \mu \mathrm{m})$ (Supplementary S9). The resulting monodisperse emulsion droplets were incubated at $37{ }^{\circ} \mathrm{C}$. After incubation, droplets were imaged by fluorescence microscopy and analyzed for the target concentration quantification.

We firstly evaluated the total reaction time of MEDICA. A customized stage was developed to capture the images of in-situ MEDICA (Supplementary S11). In the real-time MEDICA, we were able to detect significant fluorescence signals within 10 min when significant numbers of droplets are present (Figure 3a). We found the positive droplet ratio increased dramatically in 10-15 min and reached a plateau after 20 min (Figure 3b). In terms of the total fluorescence intensity, it increased until 25 min when the signals in droplets became saturated and where the amplification time $(\mathrm{Cq})$ is between 5 to $10 \mathrm{~min}$ (Figure 3c). This indicates that the real-time MEDICA only took around 5-10 min for detection which is more rapid than the corresponding assay in bulk solution. We postulated that this is because the RPA and CRISPR reactions are accelerated within a picoliter confined compartment, and the signals generated are concentrated to facilitate the detection. The enhanced mobility of molecules in a less viscous fluid in droplets also contributes to the mixing of the reagents and therefore shortens the overall reaction time. Similar results have been reported in which the reaction in droplets is accelerated ${ }^{40,41}$.

Subsequently, we calibrated MEDICA by end-point quantification using serially diluted samples of synthetic HPV 16 plasmid. The results are shown in figure 3d. The absence of the MgOAc group emitted even less fluorescence on average than the non-template control (NTC) group, which further indicates that the reaction was completely suspended without the sole magnesium co-factor. The total and positive droplets were counted using ImageJ and customized Matlab code (Supplementary S10). Figure 3e shows the fluorescence intensity from the NTC group, which was 
medRxiv preprint doi: https://doi.org/10.1101/2021.08.18.21262201; this version posted August 24, 2021. The copyright holder for this preprint (which was not certified by peer review) is the author/funder, who has granted medRxiv a license to display the preprint in perpetuity.

It is made available under a CC-BY-NC-ND 4.0 International license .

260 below the threshold. The highest intensity of the recorded droplets from the NTC group is less

261 than 0.5 after normalization, while all the positive droplets were selected over 0.6. Thus, MEDICA

262 enables near background-free digital quantification. By tailoring the reporter concentration, the

263 signal-to-background was steadily enhanced by increasing the reporting concentration

264 (Supplementary S12), which can be attributed to the unique collateral cleavage of Cas13a. We

265 obtained a linear correlation between the theoretical concentration and the measured concentration

266 (Figure 3f). We were able to quantify as low as 6 copies in total $20 \mu \mathrm{L}$ volume. Therefore,

267 MEDICA demonstrated the single-molecule detection ability and high precision quantification

268 from $0.3 \mathrm{cp} / \mu \mathrm{L}$ to $1,000,000 \mathrm{cp} / \mu \mathrm{L}$. We further tested the robustness of MEDICA to quantify HPV

$26918 \mathrm{E} 1, \mathrm{SARS}-\mathrm{CoV}-2 \mathrm{ORF}$, and $\mathrm{N}$ genes. We observed the equivalent linear correlation of all the

270 groups (Figure 3g), which further indicated the versatility of MEDICA. Finally, we tested the

271 specificity of MEDICA in multiple conditions with or without the spiked samples. Taking HPV

27216 as the main viral target, MEDICA successfully differentiated all the targets with consistent

273 results (Figure 3 h). 
a
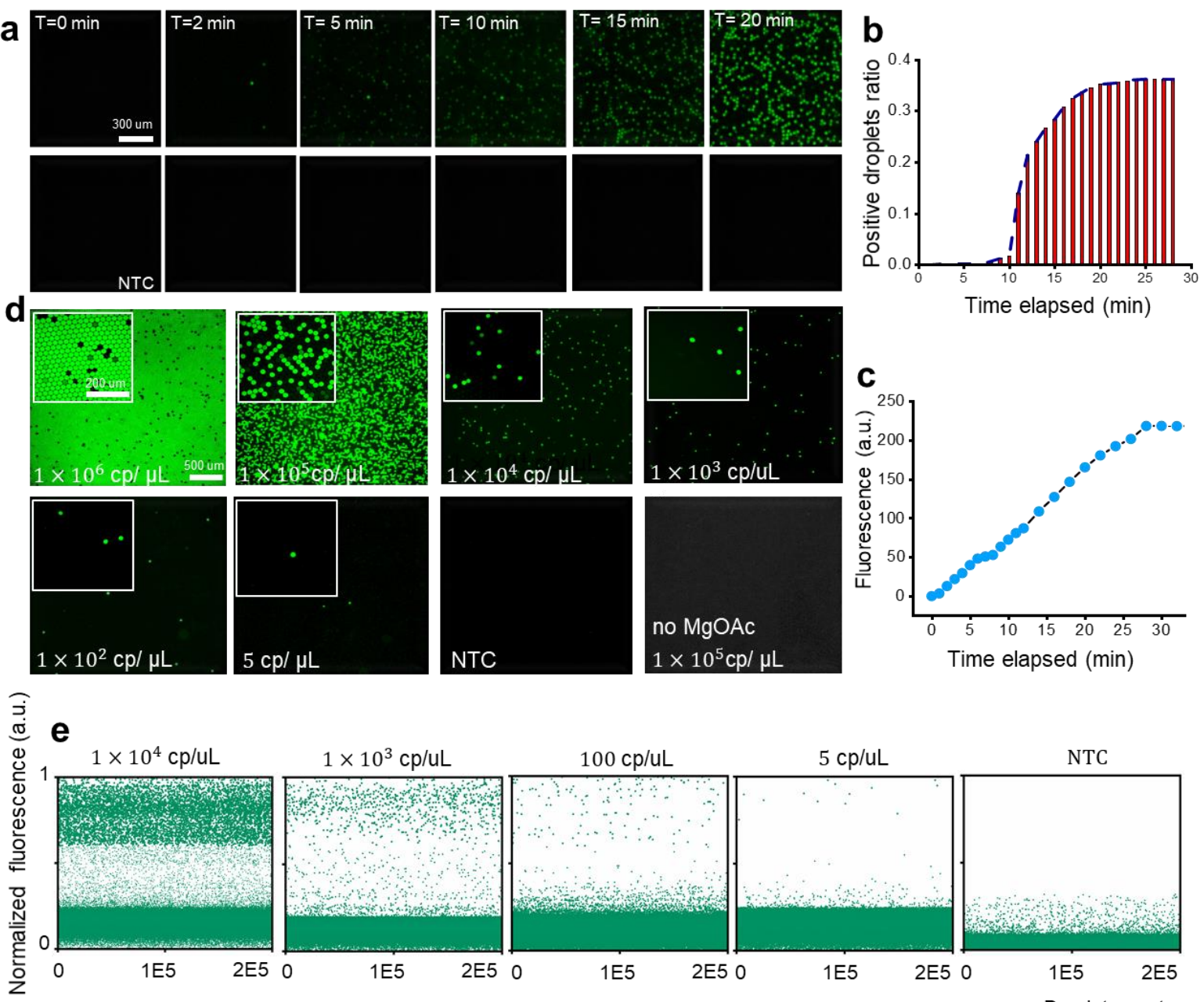

$1 \times 10^{3} \mathrm{cp} / \mathrm{uL}$

$100 \mathrm{cp} / \mathrm{uL}$
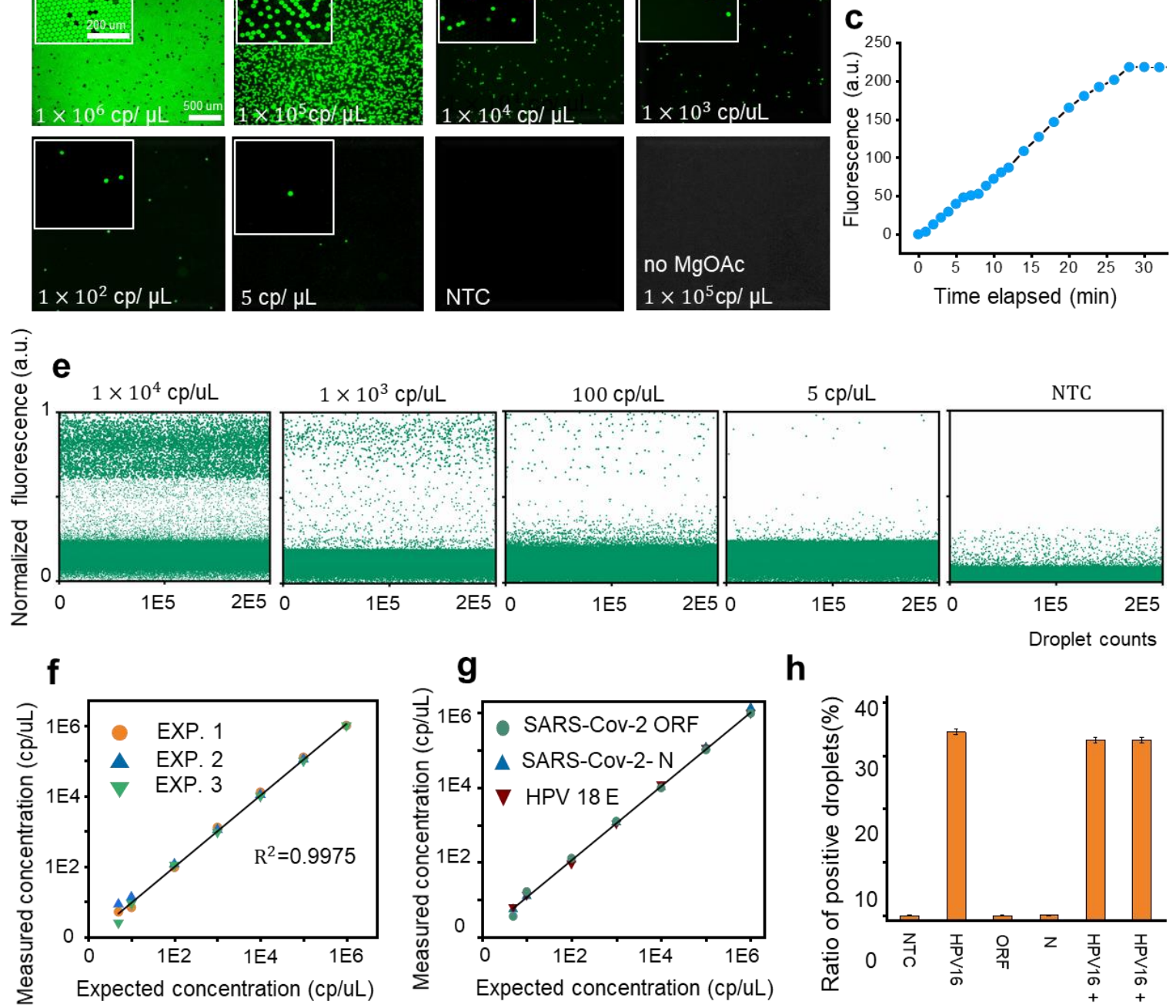

h
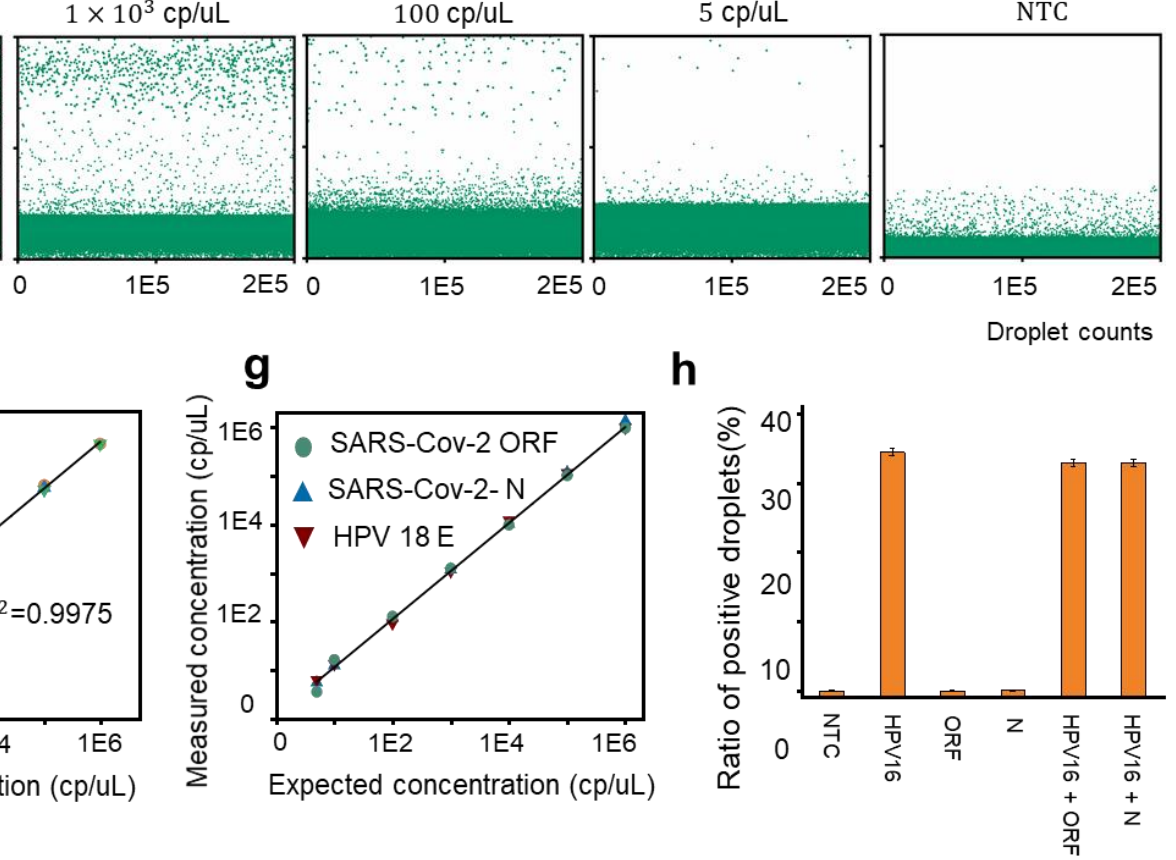

275 Figure 3. Real-time and end-point MEDICA. a, The fluorescence images of the real-time

276 MEDICA (0-20 min) for quantification of 100,000 cp/uL HPV 16 plasmid. $\mathbf{b}$, The percentage of

277 positive droplet ratio along the reaction time. 10 min was the turnover point for qualitative 
medRxiv preprint doi: https://doi.org/10.1101/2021.08.18.21262201; this version posted August 24, 2021. The copyright holder for this preprint (which was not certified by peer review) is the author/funder, who has granted medRxiv a license to display the preprint in perpetuity. It is made available under a CC-BY-NC-ND 4.0 International license.

278 detection, and the ratio was saturated around $25 \mathrm{~min}$. c, The average intensity of all droplets over

279 the reaction time. The highest fluorescence was yielded around $25 \mathrm{~min}$. d, The fluorescence images

280 of the end-point MEDICA using a serial dilution of the sample ranging from $1 \times 10^{6} \mathrm{cp} / \mu \mathrm{L}$ to

281 NTC. The extra control group was $1 \times 10^{5} \mathrm{cp} / \mu \mathrm{L}$ with the absence of the MgOAc initiator. e, The

282 statistical analysis of the end-point results. $f$, The measured concentration is in excellent agreement

283 with the expected concentration. EXP1, EXP 2, and EXP 3 represent the three technical replicated

284 experiments. g, Quantification of the SARS-CoV-2 ORF gene, SARS-CoV-2 N gene, and HPV

$28518 \mathrm{~N}$ gene by MEDICA. h, Specificity test of MEDICA to target HPV 16 with or without spiked

286 into ORF and $\mathrm{N}$ gene groups. The concentration was $1 \times 10^{5} \mathrm{cp} / \mu \mathrm{L}$. Error bars represent the $95 \%$

287 confidence interval. 


\section{Clinical validation of MEDICA}

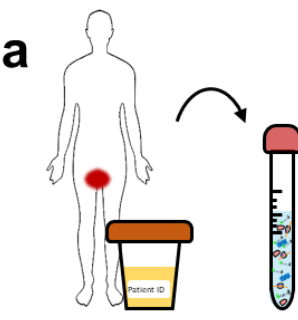

Extraction

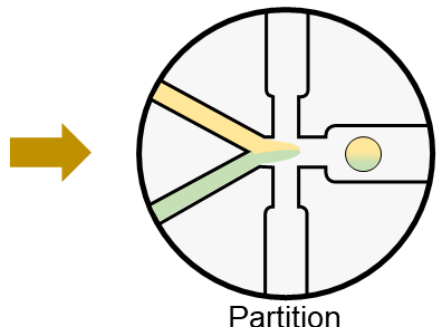

Partition

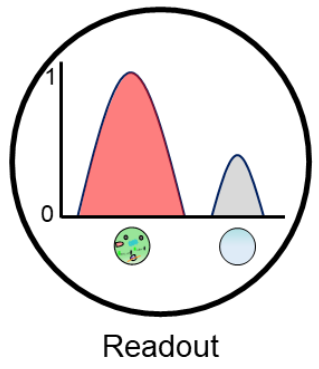

10,000

20,000

b

Concentration

(cp/uL)

MEDICA

qPCR

HPV 16 clinical sample No
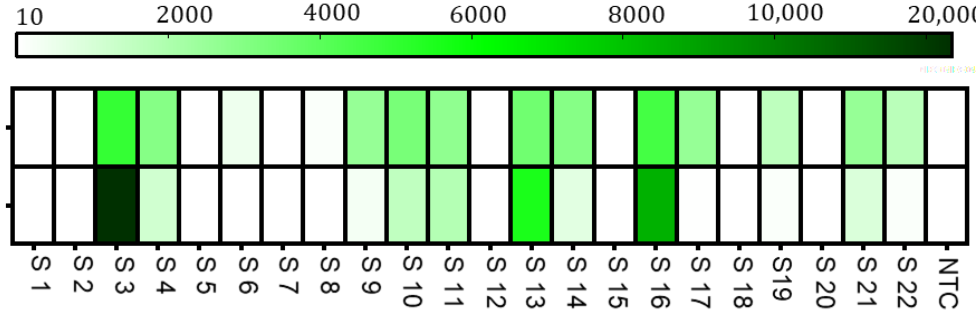

C Concentration

(cp/uL)

MEDICA

qPCR

HPV 18 clinical sample No

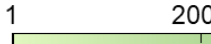

400

600

800

1000

d

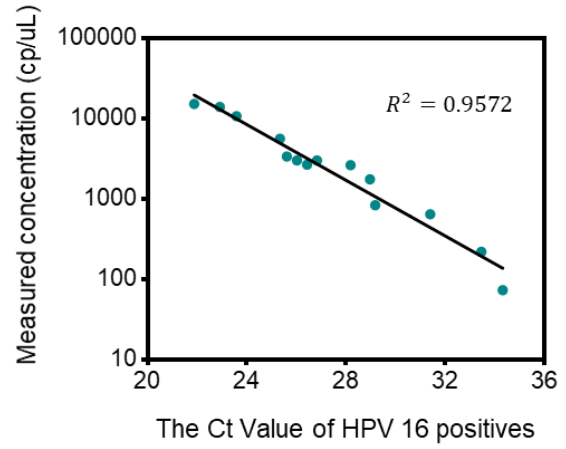

e

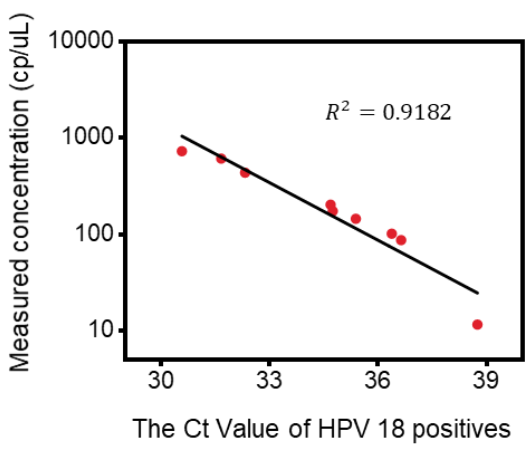

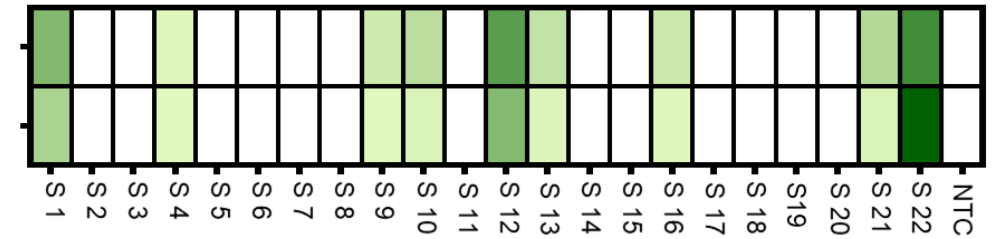

Figure 4. Clinical validation of MEDICA. a, Overview of MEDICA for viral HPV detection for detection of HPV 16. MEDICA identified all clinical samples with the same tend of qPCR. c, 
medRxiv preprint doi: https://doi.org/10.1101/2021.08.18.21262201; this version posted August 24, 2021. The copyright holder for this preprint (which was not certified by peer review) is the author/funder, who has granted medRxiv a license to display the preprint in perpetuity.

It is made available under a CC-BY-NC-ND 4.0 International license .

294 Correlation between the HPV 16 concentrations measured by MEDICA and the real-time qPCR

$295 \mathrm{C}_{\mathrm{t}}$ values. e Correlation between the HPV 18 concentrations measured by MEDICA and the real-

296 time qPCR $C_{t}$ values.

297

298 Finally, we demonstrated the feasibility of MEDICA to detect clinical viral HPV 16 and 18

299 samples. We evaluated the absolute quantification results of MEDICA with qPCR. After obtaining

300 the standard curves of qPCR for HPV 16 and HPV 18, we compared the performance of MEDICA

301 and qPCR. Both qPCR and MEDICA differentiated all the viral clinical specimens of HPV 16 and

302 HPV 18 (Figure 4b and 4c). The concentration variation of the two methods indicates the same

303 tendency. Since the $C_{t}$ (threshold cycle) values straightforwardly represent the raw target

304 concentration, we correlated the correlations of measured concentration from MEDICA with the

$305 \mathrm{C}_{t}$ values of qPCR to verify the consistency of their results. The overall correlations of the

306 measured $C_{t}$ values and the quantified concentrations from MEDICA (Figures 4d and e) follow

307 the expected trend. However, at the lowest concentration of HPV 18, the difference between these

308 two methods tended to diverge. The absolution quantification tended to decrease slower than the

309 real-time method. We believe these differences can be explained by two reasons. Firstly, when

310 the input copies are limited, the qPCR quantification is likely to have significant differences in

311 quantification results compared to the digital method ${ }^{19}$. Secondly, the concentration of the clinical

312 samples may change after several rounds of freeze-thaw, resulting in this difference. The clinical

313 validation further confirms that MEDICA offers rapid, accurate, and direct quantification of

314 nucleic acids from clinical specimens. 
medRxiv preprint doi: https://doi.org/10.1101/2021.08.18.21262201; this version posted August 24, 2021. The copyright holder for this preprint (which was not certified by peer review) is the author/funder, who has granted medRxiv a license to display the preprint in perpetuity.

It is made available under a CC-BY-NC-ND 4.0 International license .

\section{Discussion}

Identification and quantification of trace amounts of nucleic acids are of great importance for public health and molecular biology study. Herein, we developed droplet digital quantification with a one-assay of RPA and Cas13a for viral nucleic acids (MEDICA). This microfluidic assay allows rapid and sensitive nucleic acid detection within $10 \mathrm{~min}$ and $25 \mathrm{~min}$ for absolute quantification. The enhanced one-pot reaches single copy per microliter detection around 35 min. When combined with droplet microfluidics, the droplet digital method confines the singlemolecule within a single emulsion around picoliter volume to increase the localized concentration, shortening the reaction time. With simple ancillary equipment, MEDICA demonstrated a promising isothermal nucleic acid detection with Cas13a against rival thermal cycling PCR. The inborn collateral trans-cleavage of Cas 13a is harnessed for signal amplification with the increase of molecule mobility, resulting in a uniform fluorescence readout.

Compared to previously reported one-pot hot-start CRISPR assays, our enhanced one-pot reaction required a lower reaction temperature, spotlighting the promising point of care diagnostics with simple requirements. Recently, the one-pot RPA with Cas12a and Cas13a was reported to attain high sensitivity through component optimization ${ }^{4,7}$. However, these assays might be unable to achieve digital quantification due to irreproducible results by the influence of macromolecular crowding agents. This issue is originated from the RPA reaction, where the high molecular weight PEG hinders the movements of other molecules such as T7 polymerase, Cas13a nuclease, crRNA, and reporters, and thus affecting the trans-cleavage of reporters before or after CRISPR ternary activation. In PCR system, the high concentration of macromolecular crowding agent PEG is widely applied to enhance the sensitivity and specificity ${ }^{42}$. However, the high reaction temperature compared to the SHERLOCK test could increase the thermal diffusion of biomolecules, alleviating 
medRxiv preprint doi: https://doi.org/10.1101/2021.08.18.21262201; this version posted August 24, 2021. The copyright holder for this preprint (which was not certified by peer review) is the author/funder, who has granted medRxiv a license to display the preprint in perpetuity.

It is made available under a CC-BY-NC-ND 4.0 International license .

339 the inhomogeneous distribution. Therefore, at the near-ambient temperature reaction, the high

340 concentration of PEG would inevitably affect the molecule diffusion. We reduced the

341 concentration of the viscous PEG to define the trade-off between the RPA reaction and Cas 13a

342 readout for increased reproducibility. These improvements lead to the ultimate enhancement of

343 trans-reporting of Cas13a. Thus, the optimized one-pot RPA and Cas13a reaction attain fast RPA

344 reaction and powerful trans-reporting. Our optimal assay exhibits robust and reproducible

345 detection ability at a single copy per microliter.

346 Digital assays near ambient temperature could easily induce inaccuracy during manual operations

347 of sample preparation and partitioning. Hence, compartmentation technologies such as nano-wells

348 and simple flow-focusing devices may lead to the overestimated detection results. We arranged

349 the resuspension of the sole $\mathrm{MgOAc}$ initiator and master mix, enabling the reaction to be triggered

350 after monodisperse emulsion. The microfluidic approach improves the accuracy and robustness of

351 digital quantification. With the collateral enhanced one-pot assay, MEDICA achieved a uniform

352 high signal-to-background ratio, avoiding rain droplets in discrimination of the positive and

353 negative droplets. In addition, the picoliter scale reaction in droplets enhances the molecular

354 mixing and collision in confined space, greatly promoting the efficiency of this assay. Because of

355 its rapidity, sensitivity, specificity, and simple ancillary equipment, we expect that MEDICA holds

356 great potential for system integration and miniaturization for point-of-care diagnostics. 
medRxiv preprint doi: https://doi.org/10.1101/2021.08.18.21262201; this version posted August 24, 2021. The copyright holder for this preprint (which was not certified by peer review) is the author/funder, who has granted medRxiv a license to display the preprint in perpetuity.

It is made available under a CC-BY-NC-ND 4.0 International license .

Detailed information about reagents, including the commercial vendors and stock concentrations, all chemicals and sequences related to this work are listed in supplementary table 4 and table 5 .

\section{LwaCas13a protein extraction}

LwaCas13a protein extraction was performed by following a previously published protocol with minor modifications ${ }^{17}$. E. coli Rosetta 2(DE3) pLysS transformed with the pC013 TwinStrep-SUMO-huLwaCas13a expression (Addgene plasmid \#90097) and cells were cultured at $37{ }^{\circ} \mathrm{C}$ in $15 \mathrm{~mL}$ of Luria-Bertani (LB) medium containing $100 \mu \mathrm{g} / \mathrm{mL}$ ampicillin. Large-scale growth cultures were initiated by the addition of $5 \mathrm{~mL}$ of the starter cultures into $1 \mathrm{~L}$ of LB medium containing $100 \mu \mathrm{g} / \mathrm{mL}$ ampicillin and allowed to grow at $37^{\circ} \mathrm{C}$ until the $\mathrm{OD}_{600}$ reached the range of 0.4 to 0.6 . The cultures were transferred to $4{ }^{\circ} \mathrm{C}$ for $30 \mathrm{~min}$ to allow them to cool before the protein induction. The cultures were grown in a pre-chilled $16{ }^{\circ} \mathrm{C}$ biological shaker for $18 \mathrm{~h}$ with $0.1 \mathrm{mM}$ IPTG. Cells were harvested, resuspended in $4 \mathrm{X}$ (wt/vol) supplemented lysis buffer composed of $20 \mathrm{mM}$ Tris- $\mathrm{HCl}(\mathrm{pH} 8.0), 0.5 \mathrm{M} \mathrm{NaCl}, 1 \mathrm{mM}$ DTT, 2 cOmplete Ultra EDTA-free tablets, $100 \mathrm{mg}$ of lysozyme, and $1 \mathrm{uL}$ of benzonase to $60 \mathrm{~mL}$ of lysis buffer, and ruptured on ice by sonication (Q500, QSONICA). The lysate was centrifuged for $60 \mathrm{~min}$ at 10,000 rpm. at $4{ }^{\circ} \mathrm{C}$. The supernatant was collected into a $50 \mathrm{~mL}$ falcon tube, and $0.5 \mathrm{~mL}$ of Strep-Tactin superflow Plus resin was added to the supernatant. The recombinant protein was bound to the resin for $3 \mathrm{~h}$ by gentle shaking at $4{ }^{\circ} \mathrm{C}$. The resin-sample suspension was poured into $50-\mathrm{mL}$ Bio-Rad glass Econo-Column equilibrated with cold lysis buffer. After flow-through was removed, the column was washed with $50 \mathrm{~mL}$ cold lysis buffer three times. $5 \mathrm{~mL}$ of SUMO protease cleavage solution composed of $5 \mathrm{~mL}$ of lysis buffer, $50 \mu \mathrm{L}$ of SUMO protease, and $7.5 \mu \mathrm{L}$ of NP-40, was added to the column, followed by and gentle shaking at $4{ }^{\circ} \mathrm{C}$ for $18 \mathrm{~h}$. The cleavage solution was collected, and the column was washed three times with $5 \mathrm{~mL}$ of lysis buffer. The collected cleavage solution 
medRxiv preprint doi: https://doi.org/10.1101/2021.08.18.21262201; this version posted August 24, 2021. The copyright holder for this preprint (which was not certified by peer review) is the author/funder, who has granted medRxiv a license to display the preprint in perpetuity.

It is made available under a CC-BY-NC-ND 4.0 International license .

was dialyzed in $2 \mathrm{~L}$ of $1 \mathrm{X}$ PBS in a cellulose membrane dialysis tube for $18 \mathrm{~h}$. The presence of recombinant was identified using SDS-PAGE gel analysis (Supplementary S1). Amicon Ultra-0.5 $\mathrm{mL}$ centrifugal filter was used to concentrate protein and re-diluted in protein storage buffer, which allows the protein for storage at $-80{ }^{\circ} \mathrm{C}$ for up to 6 months.

\section{Clinical extraction and qPCR validation}

Clinical swab samples were provided by DiagCor Bioscience from clinical doctors in compliance with ethical and safety approval by Human Research Ethics Committee and Health, Safety and Environment Office of HKUST.

We used QIAamp DNA Mini Kit (Qiagen) to extract the viral RNAs according to the manufacturer's protocol. The raw urine sample is $10 \mathrm{~mL}$ each. After extraction, samples were collected with a $1.5 \mathrm{~mL}$ tube and stored at $-20{ }^{\circ} \mathrm{C}$ before use.

The qPCR was performed with a master mix of $20 \mu \mathrm{L}$ including $10 \mu \mathrm{L}$ of $2 \mathrm{X}$ Taq polymerase, 0.5 $\mu \mathrm{L}$ of $10 \mathrm{uM}$ forward and reverse primers each, $0.5 \mu \mathrm{L}$ of $10 \mu \mathrm{M}$ probes, $5.5 \mu \mathrm{L}$ of nuclease-free water, and $2 \mu \mathrm{L}$ of target sample from the extraction. After gentle mixing, the two-step PCR was conducted with $30 \mathrm{~s}$ pre-heating followed by 45 cycles of $5 \mathrm{~s}$ at $95{ }^{\circ} \mathrm{C}$ (denaturation) and $30 \mathrm{~s}$ at $60{ }^{\circ} \mathrm{C}$ (annealing and extension). All the qPCR experiments were conducted with a Roche Lightcycler 480 II (Roche) at HKUST BioCRF.

\section{One-step and two steps SHERLOCK}

The one-step SHERLOCK was conducted with a $20 \mu \mathrm{L}$ volume for each test. For experimental preparation, one lyophilized pellet was resuspended with $100 \mu \mathrm{L}$ of final master mix with $10 \mu \mathrm{L}$ of target and $5 \mu \mathrm{L}$ of $\mathrm{MgOAc}(280 \mathrm{mM})$ deprived. The master mix was firstly prepared including $59 \mu \mathrm{L}$ of rehydration buffer from the kit, $4 \mu \mathrm{L}$ of LwaCas13a $(1 \mu \mathrm{M}), 4 \mu \mathrm{L}$ of $\mathrm{rNTP}$ mix $(25 \mathrm{mM})$, 
medRxiv preprint doi: https://doi.org/10.1101/2021.08.18.21262201; this version posted August 24, 2021. The copyright holder for this preprint (which was not certified by peer review) is the author/funder, who has granted medRxiv a license to display the preprint in perpetuity.

It is made available under a CC-BY-NC-ND 4.0 International license .

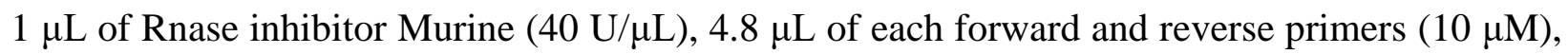
and $1.25 \mu \mathrm{L}$ of Poly $(\mathrm{U})$ reporter $(10 \mu \mathrm{M})$. After reconstitution with one lyophilized pellet with gentle mixing, this mixture was aliquoted into 5 groups $(17 \mu \mathrm{L})$. Then, $2 \mu \mathrm{L}$ of target sample and $1 \mu \mathrm{L}$ of $\mathrm{MgAOc}(280 \mathrm{mM})$ were pipetted into accordingly with quick mixing before incubation. The sample was incubated with a Roche Lightcycler 480 II (Roche) at $37{ }^{\circ} \mathrm{C}$. The fluorescence was measured every minute for one hour.

The two-step SHERLOCK is divided into two aspects: First, the RPA pre-amplification was triggered by adding $\mathrm{MgOAc}$ from the kit instructed with TwistAmp® Basic at $37{ }^{\circ} \mathrm{C}$ for $20 \mathrm{~min}$. Second, $1 \mu \mathrm{L}$ of the RPA product was added to $19 \mu \mathrm{L}$ of Cas 13 a detection master mix consisting of $20 \mathrm{mM}$ HEPES (pH 6.8), $9 \mathrm{mM} \mathrm{MgCl}_{2}, 1 \mathrm{mM}$ rNTP mix, $40 \mathrm{nM}$ LwaCas13a, $1 \mathrm{U} / \mu \mathrm{L}$ RNase inhibitor murine, $0.125 \mathrm{U} / \mu \mathrm{L}$ T7 RNA polymerase, and $125 \mathrm{nM}$ poly(U) RNA reporters. The fluorescence from the Cas13a trans-cleavage detection was then measured every $30 \mathrm{~s}$ using a Roche Lightcycler 480 II at $37^{\circ} \mathrm{C}$ for $30 \mathrm{~min}$.

\section{Buffer construction and optimization for enhanced one-pot assay}

The optimization of components of RPA and Cas13a reaction started with an initial reaction including $1 \mathrm{X}$ buffer containing $50 \mathrm{mM}$ Tris- $\mathrm{HCl}$ (pH 8.0), $60 \mathrm{mM} \mathrm{NaCl}, 5 \%$ PEG 8000, and 2 mM DTT. The initial master mix was created with $100 \mathrm{nM}$ Cas13a, $1 \mathrm{mM}$ rNTP mix, $10 \mathrm{U}$ of RNase inhibitor Murine, $100 \mathrm{nM}$ crRNA, 5U of T7 RNA polymerase, $125 \mathrm{nM}$ PolyU reporters, and $480 \mathrm{nM}$ of each forward and reverse primers, and one lyophilized pellet from the basic RPA kit. In all experiments, the master mix without $\mathrm{MgOAc}$ was used to suspend the lyophilized pellet (one pellet to $100 \mu \mathrm{L}$ final reaction volume). After reconstitution, this master mix was aliquoted accordingly, each group contains $17 \mu \mathrm{L}$ of reconstituted master mix. Then, $2 \mu \mathrm{L}$ of the synthetic 
medRxiv preprint doi: https://doi.org/10.1101/2021.08.18.21262201; this version posted August 24, 2021. The copyright holder for this preprint (which was not certified by peer review) is the author/funder, who has granted medRxiv a license to display the preprint in perpetuity.

It is made available under a CC-BY-NC-ND 4.0 International license .

427 sample or viral specimen was pipetted into this master mix with thorough mixing. Finally, $1 \mu \mathrm{L}$ of

$428 \mathrm{MgOAc}(280 \mathrm{mM})$ from the kit was added to trigger this reaction.

429 Then optimization occurred iteratively with each reagent modification. We identified each 430 component to yield the best signal then kept the optimal reagent tested previously when conducted

431 the next optimization. We evaluated the performance of Tris- $\mathrm{HCl}$ with different concentrations

$432(10,20,40,60,80$, and $100 \mathrm{mM})$ as well as $\mathrm{pH}(6.8,7.5$, and 8.0). For the salt components, we

433 tested $\mathrm{NH}_{4}\left(\mathrm{SO}_{4}\right)_{2}, \mathrm{NaCl}, \mathrm{KCl}$, and $\mathrm{CH}_{3} \mathrm{COOK}$ at different concentrations $(20,60$, and $80 \mathrm{mM})$,

434 respectively. Then, we optimized the PEG-8000 concentration $(0,2.5,5$, and $7.5 \%)$. For the

435 additives, we tested the Tween $20(0,0.05,0.1,0.2$, and $0.5 \%)$ and DTT $(0,1,4,10$, and $20 \mathrm{mM})$,

436 respectively. After the buffer construction, we further optimized primer concentration $(60,120$,

$437240,360$, and $480 \mathrm{nM})$, crRNA to Cas13a ratio $(0,0.5,1,2,3$, and 3.75), T7 polymerase $(0,0.1$,

$4380.4,0.8$, and $2 \mathrm{U} / \mu \mathrm{L})$ respectively. All the modulated reaction components are shown in figures

439 and associated figure captions.

440 E-SHERLOCK in bulk

441 The final one-pot assay contains $1 \mathrm{X}$ reaction buffer $(60 \mathrm{mM}$ Tris- $\mathrm{HCl} \mathrm{pH} 7.5,80 \mathrm{mM} \mathrm{KCl}, 2.5 \%$

442 PEG-8000, 0.05\% Tween 20 and $1 \mathrm{mM}$ DTT), $40 \mathrm{nM}$ Cas13a, $1 \mathrm{mM}$ rNTP mix, 10 U Rnase

443 inhibitor Murine, $40 \mathrm{nM}$ crRNA, $0.8 \mathrm{U} / \mu \mathrm{L}$ T7 RNA polymerase, $125 \mathrm{nM}$ Poly (U) reporters, and

$444360 \mathrm{nM}$ each forward and reverse primers, and the enzymes from the lyophilized pellet (one pellet

445 to $100 \mu \mathrm{L}$ final master mix including the target). Once the master mix is created, it is used to

446 resuspend the lyophilized pellets. The final reaction volume is $20 \mu \mathrm{L}$ containing $17 \mu \mathrm{L}$ of aliquoted

447 master mix, $2 \mu \mathrm{L}$ of target sample, and $1 \mu \mathrm{L} \mathrm{MgOAc}$ (as the last component to start this reaction). 
medRxiv preprint doi: https://doi.org/10.1101/2021.08.18.21262201; this version posted August 24, 2021. The copyright holder for this preprint (which was not certified by peer review) is the author/funder, who has granted medRxiv a license to display the preprint in perpetuity.

It is made available under a CC-BY-NC-ND 4.0 International license .

448 We further evaluated the performance of the sensitivity, specificity, and comparison of this onepot reaction. All the experiments were conducted in real-time with the Roch Lightcycler 480 II with fluorescence measurement every minute at $37^{\circ} \mathrm{C}$ for $1 \mathrm{~h}$. For the specificity test, the spiked genes were firstly prepared at $1 \times 10^{5} \mathrm{cp} / \mu \mathrm{L}$ and mixed mutually before experiments.

\section{Droplet microfluidic device design and fabrication}

The microfluidic device consists of Y-shaped two inlets for MgOAc and target-included master mix respectively, and two symmetric oil channels (fluorinated oil 7500 with $2.5 \%$ EA surfactant) to form a flow-focusing droplet generator. The thickness of this device is $35 \mu \mathrm{m}$, and all the inlets are $40 \mu \mathrm{m}$ until the flow-focusing junction with tiny modification. The aqueous phase channel of the junction is $30 \mu \mathrm{m}$ while the oil channel is $25 \mu \mathrm{m}$. The outlet channel is $100 \mu \mathrm{m}$ till the end.

The device was made of polydimethylsiloxane (PDMS, Sylgard 184 silicone elastomer, Dow deposited on a silicon wafer by spin coating. Then, the coated wafer was taken for micropatterning by employing photolithography (SUSS Mircotec MA6, Garching, Germany). Finally, the wafer was baked and developed (SU-8 developer; MicroChem, Westborough, MA, USA), forming a master for PDMS replica molding. To facilitate the molding of the PDMS device, Trichloro (1H, the surface in a desiccator. PDMS mixture was prepared by mixing PDMS and solvent at a weight ratio of 10:1, which was poured on the silicon wafer. After baking at $80{ }^{\circ} \mathrm{C}$ for 1 hour, the PDMS

467 layer was peeled off from the silicon master and then cut into an individual section. The final microfluidic chip was formed after bonding the PDMS to a glass substrate after oxygen plasma is suitable for water-in-oil droplets formation. After binding, the microfluidic chip was firstly pre- 
medRxiv preprint doi: https://doi.org/10.1101/2021.08.18.21262201; this version posted August 24, 2021. The copyright holder for this preprint (which was not certified by peer review) is the author/funder, who has granted medRxiv a license to display the preprint in perpetuity.

It is made available under a CC-BY-NC-ND 4.0 International license .

471 treated with aquapel (PPG Industries) to yield hydrophobicity and followed by fluorinated Novec

$4727100(3 \mathrm{M})$ washing for $30 \mathrm{~s}$. The microfluidic chip was incubated at a hotplate at $80{ }^{\circ} \mathrm{C}$ before use.

\section{MEDICA quantification}

474 The experiment was conducted with a pressure box (Everflow) to control the three phases

475 (magnesium phase, master mix with target and oil phase). The total reaction volume is $20 \mu \mathrm{L}$

476 containing two phases with equal volume. the $10 \mu \mathrm{L}$ of magnesium phase contains $1 \mathrm{X}$ reaction

477 buffer, $28 \mathrm{mM} \mathrm{MgOAc.} 10 \mu \mathrm{L}$ of the other phase includes $1 \mathrm{X}$ enhanced reaction buffer, $80 \mathrm{nM}$

478 Cas13a, $2 \mathrm{mM}$ rNTP, $16 \mathrm{U}$ of Rnase inhibitor Murine, $80 \mathrm{nM}$ crRNA, $1.6 \mathrm{U} / \mu \mathrm{L}$ T7 polymerase,

$479720 \mathrm{nM}$ each forward and reverse primers, $1 \mu \mathrm{M}$ poly(U) reporters, and $2 \mu \mathrm{L}$ of $1 \mathrm{X}$ target sample.

480 For end-point MEDICA, after $30 \mathrm{~min}$ incubation at $37{ }^{\circ} \mathrm{C}$, droplets were pipetted into a $30 \mu \mathrm{m}$

481 thick microchamber for fluorescence imaging. For the real-time MEDICA, firstly a heating system

482 with a Peltier on microscopy was made with a PMMA frame. The temperature was calibrated to

$48337^{\circ} \mathrm{C}$. The sample was partitioned then collected on ice. Then, all the droplets were pipetted into

484 a silicon chamber $(30 \mu \mathrm{m})$ on ice. The inlet and outlet were sealed with optical adhesive film

485 (Thermo Fisher). The time (0) image was recorded without heating. Then, the heating source was

486 opened to record the fluorescence signal evolving with time. We used the synthetic SARS-CoV-2

487 ORF plasmid as an example to measure the real-time fluorescence change. The master mix was

488 prepared with $1 \times 10^{5} \mathrm{cp} / \mu \mathrm{L}$ target input, following the same protocol as MEDICA. The 489 amplification time $(\mathrm{Cq})$ for classifying samples as positive or negative was set to approximately $49010 \%$ of the average steady state fluorescence signal.

491 The droplet imaging system includes a LED light source with a $488 \mathrm{~nm}$ filter and a Nikon 492 microscope. All the information (number and fluorescence intensity) was calculated by ImageJ 
medRxiv preprint doi: https://doi.org/10.1101/2021.08.18.21262201; this version posted August 24, 2021. The copyright holder for this preprint (which was not certified by peer review) is the author/funder, who has granted medRxiv a license to display the preprint in perpetuity.

It is made available under a CC-BY-NC-ND 4.0 International license.

$493(\mathrm{NIH})$. The detailed process of image analysis is listed in supplementary S10. According to the

494 Poisson law, the average number of target DNA per droplet $\lambda$ was calculated through the

495 possibility of positive droplets $\left(p_{\text {postive }}\right)$. Let $M$ to be the total number of droplets and $V_{\text {droplet }}$ to

496 be the average droplet volume. The molar concentration of the target $n$, can be

$\lambda=-\ln \left(1-p_{\text {postive }}\right)$

498

$$
n=\frac{\lambda}{V_{\text {droplet }}}
$$

\section{Acknowledgments}

501 We would like to thank HKUST NFF for microfluidic chip fabrication, and HKUST BioCRF for

502 the essential equipment supports. This work is supported by the University-Industry Collaboration 503 Programme (Grant No. UIM/362) under Innovation and Technology Fund of Hong Kong.

\section{Author contributions}

S.Y. and B.T. conceived and supervised the project. F.L., Q.C. and H.P designed the research. H.P

507 purified the proteins and performed the verification. F.L. developed the assay and clinical PCR

508 validation. F.L. and Q.C developed the microfluidic chip and conducted the droplet quantification experiments. Q.C developed the method for droplet analysis. K.C and T.L collected and purified

510 all the clinical samples. F.L., Q.C., and H.P., analysed the data. F.L., Q.C., H.P., and S.Y. wrote 511 the manuscript. All authors edited the manuscript. 
medRxiv preprint doi: https://doi.org/10.1101/2021.08.18.21262201; this version posted August 24, 2021. The copyright holder for this preprint (which was not certified by peer review) is the author/funder, who has granted medRxiv a license to display the preprint in perpetuity.

It is made available under a CC-BY-NC-ND 4.0 International license .

\section{Competing interests}

514 The authors declare no competing interests.

515

516 References

517 1. Wang, C., Horby, P. W., Hayden, F. G. \& Gao, G. F. A novel coronavirus outbreak of global

518 health concern. The lancet 395, 470-473 (2020).

519 2. Vogels, C. B. et al. Analytical sensitivity and efficiency comparisons of SARS-CoV-2 RT-

520 qPCR primer-probe sets. Nature microbiology 5, 1299-1305 (2020).

521 3. Ackerman, C. M. et al. Massively multiplexed nucleic acid detection with Cas13. Nature 582,

$522 \quad 277-282(2020)$.

523 4. Arizti-Sanz, J. et al. Streamlined inactivation, amplification, and Cas13-based detection of

524 SARS-CoV-2. Nature communications 11, 1-9 (2020).

525 5. Barnes, K. G. et al. Deployable CRISPR-Cas13a diagnostic tools to detect and report Ebola 526 and Lassa virus cases in real-time. Nature communications 11, 1-10 (2020).

527 6. Broughton, J. P. et al. CRISPR-Cas12-based detection of SARS-CoV-2. Nat. Biotechnol. 38, $528 \quad 870-874(2020)$.

529 7. Ding, X. et al. Ultrasensitive and visual detection of SARS-CoV-2 using all-in-one dual

530 CRISPR-Cas12a assay. Nature communications 11, 1-10 (2020). 
medRxiv preprint doi: https://doi.org/10.1101/2021.08.18.21262201; this version posted August 24, 2021. The copyright holder for this preprint (which was not certified by peer review) is the author/funder, who has granted medRxiv a license to display the preprint in perpetuity.

It is made available under a CC-BY-NC-ND 4.0 International license .

531 8. Gootenberg, J. S. et al. Multiplexed and portable nucleic acid detection platform with Cas13,

532 Cas12a, and Csm6. Science 360, 439-444 (2018).

533 9. Joung, J. et al. Detection of SARS-CoV-2 with SHERLOCK one-pot testing. N. Engl. J. Med.

$534383,1492-1494(2020)$.

535 10. Patchsung, M. et al. Clinical validation of a Cas13-based assay for the detection of SARS-

536 CoV-2 RNA. Nature Biomedical Engineering 4, 1140-1149 (2020).

537 11. Knott, G. J. \& Doudna, J. A. CRISPR-Cas guides the future of genetic engineering. Science

538 361, 866-869 (2018).

539 12. Chertow, D. S. Next-generation diagnostics with CRISPR. Science 360, 381-382 (2018).

540 13. Gootenberg, J. S. et al. Nucleic acid detection with CRISPR-Cas13a/C2c2. Science 356, 438-

$541442(2017)$.

542 14. Chen, J. S. et al. CRISPR-Cas12a target binding unleashes indiscriminate single-stranded

543 DNase activity. Science 360, 436-439 (2018).

544 15. East-Seletsky, A., O’Connell, M. R., Burstein, D., Knott, G. J. \& Doudna, J. A. RNA

545 targeting by functionally orthogonal type VI-A CRISPR-Cas enzymes. Mol. Cell 66, 373-383. e3

546 (2017).

547 16. Ramachandran, A. \& Santiago, J. G. CRISPR Enzyme Kinetics for Molecular Diagnostics.

548 Anal. Chem. (2021). 
medRxiv preprint doi: https://doi.org/10.1101/2021.08.18.21262201; this version posted August 24, 2021. The copyright holder for this preprint (which was not certified by peer review) is the author/funder, who has granted medRxiv a license to display the preprint in perpetuity.

It is made available under a CC-BY-NC-ND 4.0 International license .

25. Yue, H. et al. Droplet Cas12a Assay Enables DNA Quantification from Unamplified

17. Kellner, M. J., Koob, J. G., Gootenberg, J. S., Abudayyeh, O. O. \& Zhang, F. SHERLOCK: nucleic acid detection with CRISPR nucleases. Nature protocols 14, 2986-3012 (2019).

18. Sedlak, R. H. \& Jerome, K. R. Viral diagnostics in the era of digital polymerase chain reaction. Diagn. Microbiol. Infect. Dis. 75, 1-4 (2013).

19. Hindson, C. M. et al. Absolute quantification by droplet digital PCR versus analog real-time PCR. Nature methods 10, 1003-1005 (2013).

20. Salipante, S. J. \& Jerome, K. R. Digital PCR — an emerging technology with broad applications in microbiology. Clin. Chem. 66, 117-123 (2020).

21. Lin, X., Huang, X., Urmann, K., Xie, X. \& Hoffmann, M. R. Digital loop-mediated isothermal amplification on a commercial membrane. ACS sensors 4, 242-249 (2019).

22. Abd El Wahed, A. et al. A portable reverse transcription recombinase polymerase amplification assay for rapid detection of foot-and-mouth disease virus. PloS one 8, e71642 (2013).

23. Ooi, K. H. et al. An engineered CRISPR-Cas12a variant and DNA-RNA hybrid guides enable robust and rapid COVID-19 testing. Nature communications 12, 1-23 (2021).

24. Park, J. S. et al. Digital CRISPR/Cas-Assisted Assay for Rapid and Sensitive Detection of SARS-CoV-2. Advanced Science 8, 2003564 (2021).

567 Samples at the Single-Molecule Level. Nano Letters (2021). 
medRxiv preprint doi: https://doi.org/10.1101/2021.08.18.21262201; this version posted August 24, 2021. The copyright holder for this preprint (which was not certified by peer review) is the author/funder, who has granted medRxiv a license to display the preprint in perpetuity.

It is made available under a CC-BY-NC-ND 4.0 International license .

568

569

570

571

572

573

574

575

576

577

578

579

580

581

582

583

584

585
26. Tian, T. et al. An Ultralocalized Cas13a Assay Enables Universal and Nucleic Acid Amplification-Free Single-Molecule RNA Diagnostics. ACS Nano (2020).

27. Wu, X. et al. Digital CRISPR-based method for the rapid detection and absolute quantification of nucleic acids. Biomaterials, 120876 (2021).

28. Woodman, C. B., Collins, S. I. \& Young, L. S. The natural history of cervical HPV infection: unresolved issues. Nature Reviews Cancer 7, 11-22 (2007).

29. Piepenburg, O., Williams, C. H., Stemple, D. L. \& Armes, N. A. DNA detection using recombination proteins. PLoS Biol 4, e204 (2006).

30. Zhao, Y., Chen, F., Li, Q., Wang, L. \& Fan, C. Isothermal amplification of nucleic acids. Chem. Rev. 115, 12491-12545 (2015).

31. Yeh, E. et al. Self-powered integrated microfluidic point-of-care low-cost enabling (SIMPLE) chip. Science advances 3, e1501645 (2017).

32. Li, J., Macdonald, J. \& von Stetten, F. a comprehensive summary of a decade development of the recombinase polymerase amplification. Analyst 144, 31-67 (2018).

33. Cohen, L. et al. Single molecule protein detection with attomolar sensitivity using droplet digital enzyme-linked immunosorbent assay. ACS nano 14, 9491-9501 (2020).

34. Wu, C., Garden, P. M. \& Walt, D. R. Ultrasensitive detection of attomolar protein concentrations by dropcast single molecule assays. J. Am. Chem. Soc. 142, 12314-12323 (2020). 
medRxiv preprint doi: https://doi.org/10.1101/2021.08.18.21262201; this version posted August 24, 2021. The copyright holder for this preprint (which was not certified by peer review) is the author/funder, who has granted medRxiv a license to display the preprint in perpetuity.

It is made available under a CC-BY-NC-ND 4.0 International license .

586

587

588

589

590

591

592

593

594

595

596

597

598

599

600

601
35. Gootenberg, J. S. et al. Multiplexed and portable nucleic acid detection platform with Cas13, Cas12a, and Csm6. Science 360, 439-444 (2018).

36. Trypsteen, W. et al. ddpcRquant: threshold determination for single channel droplet digital PCR experiments. Analytical and bioanalytical chemistry 407, 5827-5834 (2015).

37. Kaminski, M. M., Abudayyeh, O. O., Gootenberg, J. S., Zhang, F. \& Collins, J. J. CRISPRbased diagnostics. Nature Biomedical Engineering 5, 643-656 (2021).

38. Lillis, L. et al. Factors influencing Recombinase polymerase amplification (RPA) assay outcomes at point of care. Mol. Cell. Probes 30, 74-78 (2016).

39. Baret, J. Surfactants in droplet-based microfluidics. Lab on a Chip 12, 422-433 (2012).

40. Gines, G. et al. Isothermal digital detection of microRNAs using background-free molecular circuit. Science advances 6, eaay5952 (2020).

41. Kalsi, S. et al. Rapid and sensitive detection of antibiotic resistance on a programmable digital microfluidic platform. Lab on a Chip 15, 3065-3075 (2015).

42. Ellis, R. J. Macromolecular crowding: obvious but underappreciated. Trends Biochem. Sci.

26, 597-604 (2001). 